УДК 81’22’367’373.7:821.112.2

DOI https://doi.org/10.26661/2414-1135-2021-81-2-2

\title{
ВЕРБАЛЬНІ ЗАСОБИ ОБ'СКТИВАЦІЇ КОНЦЕПТУ «ЗАПАХ» У РОМАНІ ПАТРІКА ЗЮСКІНДА «ПАРФУМИ. ІСТОРІЯ ОДНОГО ВБИВЦІ»
}

\author{
Мукатаєва Я. В. \\ кандидат філологічних наук, дочент, \\ доцент кафедри романо-германської філології та перекладу з німецької мови \\ Чорноморський національний університет імені Петра Могили \\ вул. 68 Десантників, 10, Миколаїв, Україна \\ orcid.org/0000-0003-3812-8424 \\ jara53@meta.ua
}

\begin{abstract}
Ключові слова: вербалізачія, когнітивна парадигма, номінативні та денотативні репрезентанти, синтаксична стилістика кониепту, метафори, фразеологізми.
\end{abstract}

У статті розглядаються засоби вербалізації концепту «запах» на лексичному, синтаксичному i фразеологічному рівнях на матеріалі роману Патріка Зюскінда «Парфуми. Історія одного вбивці». Зазначається, що саме ці чинники формують мовну і концептуальну картини світу. Методологічною основою дослідження $є$ вивчення проблематики з позиції сучасної когнітивної парадигми. Аналізуються різні підходи щодо тлумачення понять «концепт» і «художній концепт», які $€$ основними одиницями мовної картини світу письменника. Від мовних концептів і концептів культури текстові (художні) концепти відрізняються змістом і способом презентації на вербальному рівні, а також обсягом об'єктивації, який є здебільшого фіксованим Мова роману тісно пов'язана з мисленням і мовленнєвою діяльністю індивіда (у нашому випадку головного героя роману), його чуттєво-нюховим ставленням до навколишнього середовища у процесі його пізнання. Ольфакторний концепт «запах» $є$ основним ідейнотворчим елементом індивідуально-авторської концептуальної картини Патріка Зюскінда, вважається безпрецедентним прикладом художнього тексту, у якому значне місце відводиться ольфакторним образам, що презентуються найрізноманітнішими вербальними засобами на різних рівнях мови. У романі відбивається специфіка авторського світобачення, актуалізуються ті рівні значень і смислів, які є аксіологічно вагомими та цікавими для адресата. Концепт «запах» є ключовим серед перцептивних концептів, оскільки він пов'язаний із нюховим сприйняттям дійсності, що певною мірою ускладнює його відтворення і потребує детального аналізу на вербальному рівні. У науковій розвідці здійснюється комплексний аналіз лексичної, синтаксичної та фразеологічної об’єктивації концепту «запах» у зазначеному художньому тексті, зокрема його номінативні та денотативні репрезентанти, зосереджується увага на дослідженні синтаксичної стилістики концепту «запах». Визначається статус концепту «запах» в індивідуально-авторській концептосфері Патріка Зюскінда, аналізуються найуживаніші види метафор, які виступають репрезентантами зазначеного концепту, зосереджується увага на його репрезентації на фразеологічному рівні. 


\title{
VERBAL MEANS OF OBJECTIFICATION OF THE CONCEPT "SMELL" IN PATRICK SUSKIND'S NOVEL "PERFUMES. THE STORY OF ONE KILLER"
}

\author{
Mukataieva Ya. V. \\ Candidate of Philological Sciences, Associate Professor, \\ Associate Professor at the Roman-Germanic Philology and Translation in German Department \\ Petro Mohyla Black Sea National University \\ 68 Desantnykiv str., 10, Mykolaiv, Ukraine \\ orcid.org/0000-0003-3812-8424 \\ jara53@meta.ua
}

Key words: verbalization, cognitive paradigm, nominative and denotative representing, syntactic stylistics of the concept, metaphors, phraseological units.

\begin{abstract}
The article is dedicated to the problem of verbalization of the concept "smell" on the lexical, syntactical and phraseological levels on the material of Patrick Süskind's novel "Perfume. The story of one killer." It is noted that these factors form the linguistic and conceptual picture of the world. The methodological basis of the study is the study of problems from the point of position of modern cognitive paradigm. Different approaches to the interpretation of the notions "concept" and "artistic concept", which are the main units of the language picture of the writer's world, are analyzed. Text (artistic) concepts differ from language concepts and concepts of culture in the content and method of presentation at the verbal level, as well as the volume of objectification, which is mostly fixed. The language of the novel is closely related to the thinking and speech activities of the individual (in our case, the protagonist of the novel), his sensual-sniffing attitude to the environment in the process of his knowledge. The olfactory concept "smell" is the main idea-forming element of the individual-author's conceptual picture of Patrick Süskind, and is considered to be an unprecedented example of artistic text, in which a significant place is given to olfactory images presented by a wide variety of verbal means at different levels of speech. The novel reflects the specifics of the author's world-perception, those levels of values and meanings that are axiologically significant and interesting for the addressee are updated. The concept "smell" is key among perceptive concepts, since it is associated with the sense of smell perception of reality, which to some extent complicates its reproduction and requires detailed analysis at the verbal level. In scientific research a comprehensive analysis of the lexical, syntactic and phraseological objectification of the concept "smell" in the specified artistic text, in particular its nominative and denotative representations, focuses on the study of the syntactic stylistics of the concept "smell". The status of the concept "smell" in Patrick Süskind's individual-author's concept-sphere is determined, the most common types of metaphors that are representative of this concept are analyzed, and the attention is focused on its representation on the phraseological level.
\end{abstract}

Постановка проблеми. Розвиток антропоцентричної парадигми зумовив зростання інтересу науковців до вивчення художнього тексту в межах таких актуальних напрямів сучасної лінгвістики, як когнітивна лінгвістика, психолінгвістика, комунікативна лінгвістика. Дослідження вербальних засобів об'єктивації текстових концептів є важливим завданням лінгвоконцептології. Оскільки текстові концепти тісно пов'язані з національною свідомістю і культурою народу, то вони часто виступають об'єктом лінгвостилістичного і лінгвокогнітивного аналізу. Одним із таких концеп- тів є концепт «запах», він посідає чільне місце в романі Патріка Зюскінда «Парфуми. Історія одного вбивці». Для повноти лінгвістичних досліджень роману Патріка Зюскінда «Парфуми. Історія одного вбивці» становить інтерес аналіз організації інформації, знань і образно-художніх конструктів художнього тексту засобами вербалізації.

Метою наукової розвідки $\epsilon$ комплексний аналіз лексичної, синтаксичної та фразеологічної об'єктивації концепту «запах» в романі Патріка Зюскінда «Парфуми. Історія одного вбивці». 3 метою реалізації поставленої мети передбача- 
ється вирішення таких завдань: дослідити різні підходи до тлумачення текстового концепту та його особливості; схарактеризувати номінативні та денотативні репрезентанти концепту «запах» у романі; зробити аналіз синтаксичної стилістики концепту «запах» і його репрезентацію на фразеологічному рівні.

Об'сктом дослідження виступає концепт «запах» у романі П. Зюскінда «Парфуми». Предметом дослідження є вербальні засоби об'єктивації концепту «запах» у романі П. Зюскінда.

Виклад основного матеріалу дослідження. В Україні розвиток лінгвокогнітивної лінгвістики пов'язаний 3 іменами О.П. Воробйової, С.А. Жаботинської, А.П. Мартинюк, О.I. Морозової, А.М. Приходька, І.С. Шевченко та ін.

Існують різні підходи до тлумачення поняття «текстовий концепт» Виступаючи ключовою одиницею когнітивної парадигми, художні (текстові) концепти уможливлюють розуміння індивідуального стилю та світосприйняття автора під іншим кутом. Художні концепти відрізняються від мовних концептів і концептів культури «змістом і способом експлікації, обсягом та історичною мінливістю» [2, с. 115], а також тим, що вони є основними одиницями концептуальної картини світу письменника. Л.В. Міллер трактує художній концепт як індивідуально-авторське ментальне формування й елемент національної художньої традиції, національної художньої картини світу, наголошуючи на тому, що концепт належить не тільки індивідуальній свідомості, але і психоментальній сфері окремої етнокультурної спільноти [6, с. 41].

Художній концепт ототожнюють із текстовим концептом, розуміючи під цим поняттям «кодоване мовленнєво-розумове утворення змістового плану, яке зумовлене багатосмисловою напруженістю художнього тексту та характеризується надкатегоріальністю й імплікує сукупність ознакових рис художнього твору» [3, с. 56]. У текстовому концепті, на думку О.В. Сердюк, окрім асоціативного простору мислення автора, також $\epsilon$ простір для мислення читача, адже письменник постійно веде внутрішній діалог зі своїм потенційним реципієнтом. Таким чином, у художньому творі відбивається як специфіка авторського світобачення, так і актуалізуються ті рівні значень і смислів, що є аксіологічно вагомими, цікавими для читача [8, с. 141].

До індивідуально-авторських концептів належать унікальні оригінальні ментально-вербальні конструкти, аналогів яких немає серед концептів-універсалій і яких не існує у мовній картині світу середнього носія мови. Такі концепти є власне авторськими неологізмами [9, с. 99]. Обсяг текстового концепту є здебільшого фіксованим, оскільки він обмежений рамками окремого твору чи кількома творами того чи іншого письменника. Це уможливлює виявлення усіх характеристик (концептуальних атрибутів) концептів через засоби їх мовної реалізації, адже їхня кількість обмежена обсягом самого художнього твору [1].

Знання, образи й асоціації, що нашаровуються на поняття через знаковий код мови, є глибоко інтеріоризованими в кожної мовленнєвої особистості та становлять лінгвокультурну цінність концепту [7, с. 62]. Мовна картина світу - це та частина культурно-концептуальної картини, яка отримала означення засобами мови i, таким чином, може бути піддана аналізу на рівні мовних одиниць. Вона містить, окрім знань про мову, інформацію, що доповнює зміст концептуальної картини світу за рахунок мовних засобів. Різниця між концептуальною і мовною картинами світу полягає у тому, що мовна картина світу оперує мовними знаками, а концептуальна - образами й концептами. Разом вони здатні об’єднуватися у фрейми [7, с. 23].

Питання вербалізації концептів у німецькомовній картині світу неодноразово висвітлювалися у наукових розвідках. Аналізуючи концепт «шлях» у німецькомовному казковому дискурсі, ми встановили національно-специфічний характер цього концепту, у якому закладені ціннісні уявлення німецького народу про навколишній світ, специфіка сприйняття німецьким етносом категорій простору, руху, часу [4].

Роботи російської лінгвістки Ю.А. Старостіної присвячені способам і засобам вербалізації концепту «запах» у романі П. Зюскінда «Запахи» на прикладі аналізу різних видів метафор. У науковій розвідці було встановлено, що домінантною структурною моделлю репрезентації ольфакторного простору в романі слугує розгорнута метафора, яка найбільш повно розкриває семантику слів-номінантів концепту «запах». Крім того, об'єктом досліджень російської лінгвістки стали корелятивні зв’ язки між концептами «краса» та «запах»у романі, чому і присвячені деякі наукові статті [10].

H.I. Лєпухова у своїх наукових розвідках висвітлила особливості відтворення концептосфери роману П. Зюскінда «Запахи. Історія одного вбивці» в українському перекладі. Методом концептуального аналізу встановлено домінуючу роль концепту «запах» у романі, основні засоби та прийоми його репрезентації, також виявлено відмінності у відтворенні концепту мовними засобами під час перекладу українською мовою [5].

Серед перцептивних концептів, пов'язаних iз нюховим сприйняттям, беззаперечно, виділяють концепт «запах». Саме у цьому концепті закладені знання про нюхові, ароматичні особливості, які притаманні тому чи іншому об'єкту. Головний герой роману Патріка Зюскінда «Парфуми. Історія одного вбивці» Жан-Батіст Гренуй володіє уні- 
кальним, надприродним даром розрізняти найтонші аромати, хоча він сам позбавлений власного запаху. Слід зазначити, що ольфакторний концепт «запах» виступає основним ідейнотворчим елементом індивідуально-авторської концептосфери. Ольфакторні образи, якими пронизано весь текст роману, виражаються найрізноманітнішими вербальними засобами на усіх рівнях мови.

Для вербального відтворення концепту «запах» у романі П. Зюскінд використовує лексичну, синтаксичну і фразеологічну об'єктивації. Лексична об'єктивація концепту відбиває найпродуктивніший спосіб його вербального втілення, а саме однослівний [7, с, 108]. Одним зі способів словотворення для їх експлікації автор використовує складні іменники на позначенням об'єкта, який $\epsilon$ джерелом розповсюдження притаманних для нього запахів. За допомогою композитів позначаються запахи, що зчитуються та розпізнаються головним героєм у процесі нюхового сприйняття, а деякі з них створені ним особисто. Носіями цих запахів можуть виступати як об'єкти з матеріального світу, так і деякі абстрактні поняття, ольфакторний потенціал яких у реальному світі залишиться нерозкритим оточуючими.

Серед номінативних репрезентантів концепту «запах» найбільш уживаними є іменники der Geruch i der Duft, саме вони формують понятійну складову частину концепту. Незважаючи на те, що ці слова позначають запахи, вони не є абсолютними синонімами та мають певні відмінності на семантичному рівні. Іменник $\mathrm{der}$ Geruch та усі похідні від нього слова $є$ нейтральними одиницями-репрезентантами концепту «запах», адже в романі вони використовуються для позначення як приємних, так і неприємних запахів.

На різницю між семантичним значенням цих іменників вказують репрезентовані прикметники, які містять яскраво виражений оціночний компонент: der Geruch (groß, scharf, beizend) - домінантними $є$ саме прикметники 3 негативною конотацією - та der Duft (angenehm, fein, unbeschreiblich, herrlich, einzigartig, geliebt) - автор роману акцентує увагу на позитивному забарвленні, унаслідок чого підкреслюється висока естетична цінність ольфакторних образів. Патрік Зюскінд часто звертається до вербальних засобів, котрі мають негативне семантичне забарвлення, наприклад лексема der Gestank і всі похідні від неї слова. Ольфакторне середовище зображено на початку роману, автор детально описує суцільний сморід, що панує у найвіддаленіших закутках Парижа:

Es stanken die Straßen nach Mist, es stanken die Hinterhofe nach Urin, es stanken die Treppenhäuser nach fauligem Holz und nach Rattendreck, die Küchen nach verdorbenem Kohl und Hammelfett; die ungelüfteten Stuben stanken nach muffigem Staub, die Schlafzimmer nach fettigen Laken, nach feuchten Federbetten und nach dem stechend süßen Duft der Nachttöpfe [11, c. 5-6].

До денотативних засобів репрезентації концепту в романі слід віднести композити 3 компонентами der Geruch i der Duft, наприклад: das Geruchsorgan, der Geruchssinn, das Geruchserlebnis та ін. Складних іменників 3 іншим компонентом der Duft у романі кількісно більше, серед них виділяються приклади: die Duftkombination, das Duftatom, das Duftgewerbe, der Duftkorn, das Brillantduftfeuerwerk, das Duftkunststück, das Duftdiadem, das Duftkleid, der Duftpanzer, das Duftragment та ін. Авторські новоутворення виділяються серед решти лексем особливо високою образністю (das Geruchsrevier, das Duftdiadem, die Duftmaske, das Brillantduftfeuerwerk) і посідають у романі значне місце.

Гренуй може однаково легко розпізнавати: запах рослини або дерева (der Wurzelgeruch, der Holzgeruch, der Lavendelduft, der Moschusduft); запах моря (der Meergeruch); запах людини або тварини (der Menschengeruch, der Säuglingsgeruch, der Hundeduft); відчувати своїм носом запах надії (der Hoffnungsgeruch); створити запахи непомітності (der Unauffälligkeitsgeruch) чи невинності (der Unschuldsgeruch).

Метафора $\epsilon$ провідним репрезентантом концепту «запах» у романі. П. Зюскінд ототожнює у романі запахи зі смаками, використовуючи назви страв. Так, наприклад, автор відтворює образ Парижа за допомогою так званої гастрономічної метафори: він називає його кашею, у якій змішані тисячі ароматів:

Tausende und Abertausende von Gerüchen bildeten einen unsichtbaren Brei, der die Schluchten der Gassen anfüllte, sich über den Dächern nur selten, unten am Boden niemals verflüchtigte [1, c. 44].

Для концептуалізації запаху автор використовує так звані архітектурні метафори, уподібнюючи їх спорудам: кімнатам, будинкам, вежам. використана архітектурна метафора.

Und bald schon konnte er beginnen, die ersten planvollen Geruchsgebäude aufzurichten: Häuser, Mauern, Stufen, Türme, Keller, Zimmer, geheime Gemächer... [11, c. 58].

Важливу роль у зображенні концепту «запах» відіграє синтаксична об'єктивація. Для відтворення концепту «запах» автор використовує стильові прийоми інверсії, епіфори, повтори тощо.

Інверсія (порушення структури речення задля створення емоційно-смислових відтінків) є одним зі способів синтаксичного вираження концепту «запах» у романі. За допомогою цього стилістичного засобу П. Зюскінд зосереджує увагу читача саме на запахах, їхній якості або джерелах їх походження. 
Nach Haaren konnte er riechen, nach Haut und Haaren und vielleicht nach ein bisschen Kinderschweiß $[11$, c. 21]

Задля надання тексту експресивності автор часто використовує епіфори. Так наприклад, описуючи сон, у якому Гренуй ледь не задихнувся від власного ж запаху, вжито епіфору (повторення лексеми Geruch наприкінці кожного речення).

Und der Nebel war, wie gesagt, ein Geruch. Und Grenouille wusste auch, was für ein Geruch. Der Nebel war sein eigener Geruch. Sein, Grenouilles, Eigengeruch war der Nebel [11, c. 171].

3 метою увиразнення та виокремлення кожного окремого запаху П. Зюскінд вдається до стилістичного прийому полісиндетону (нагромаджень сполучників і прийменників у реченні).

Er las von den Gerüchen seiner Kindheit, von den Schulgerüchen, von den Gerüchen der Straßen und Winkel der Stadt, von Menschengerüchen [11, c. 158].

Фразеологічний рівень об'єктивації має дві площини - мовну (фразеологічна одиниця тотожна концепту) і мовленнєву (фразеологічна одиниця висвітлює якусь рису концепту [7, с. 109] На фразеологічному рівні концепт «запах» у романі П. Зюскінда репрезентовано фразеологічними одиницями, в основі яких лежать соматизми - лексичні компоненти, що позначають органи людського тіла. Наведемо приклад фразеологізмів із лексемою die Nase.

Du hast, so scheint es, eine feine Nase, junger Mann, sagte er, nachdem Grenouille mit seinem Gekrächze aufgehört hatte, und trat zurück in die Werkstatt, um den Leuchter vorsichtig auf dem Arbeitstisch abzustellen, eine zweifellos feine Nase, aber... / Ich habe die beste Nase von Paris, Maitre Baldini [11, c. 95];

У наведеному прикладі декілька разів зустрічається фразеологізм eine feine Nase haben/besitzen. Залежно від контексту він набуває прямого або переносного значення.

Прикладом поєднання кількох соматичних фразеологізмів слугує уривок, у якому описуються відчуття Гренуєм запаху дерева. Зюскінд образно зіставляє Гренуя із потопаючим, який захлинається від аромату свіжо зрублених полін, а сам запах - із водою. Це стає зрозумілим завдяки дієслову ertrinken (nomonaтu).

Er trank diesen Duft, er ertrank darin [11, c. 32].

Концепт «запах» на фразеологічному рівні також репрезентовано стійкими ідіоматичними словосполученнями із такими базисними лексемами, як der Duft та der Geruch (einen Duft von der Stirne ablesen, Gerüche enträtseln, einen Duft in der Nase haben, den Duft des Mädchens ernten, im Banne des Duftes stehen, einen Duft zerspalten, die Gerüche in sich tragen, den Duft aus den Kellern des Herzens trinken).
Висновки і перспективи подальших розробок. Отже, концепт «запах» у романі Патріка Зюскінда розкривається шляхом вербальної презентації на лексичному і синтаксичному рівнях стилістики, а також за допомогою використання фразеологізмів. Перспективою подальших досліджень цього концепту вважаємо аналіз його фреймової презентації, а також зіставлення в німецькомовній та україномовній картинах світу.

\section{ЛІТЕРАТУРА}

1. Губа Л.В. Художній концепт як репрезентант поетичної мовної свідомості. Молодий вчений. 2018. № 3 (2). С. 616-619.

2. Доценко P.I. На підступах до стилю письменника. Всесвіт. 1971. № 9. С. 114-117.

3. Кагановська О.М. Текстові концепти художньої прози (на матеріалі французької романістики середини XX сторіччя). Київ : вид. центр КНЛУ, 2002. 292 с.

4. Кирилюк С.В. Лінгвокогнітивні характеристики концепту WEG / ДОРОГА в німецькій народній казці : автореф. дис. ... канд. філол. наук : 10.02.04. Запоріжжя, 2016. 20 с.

5. Лєпухова Н.І. Особливості відтворення концептосфери художнього твору при перекладі українською мовою (на матеріалі роману П. Зюскінда «Запахи. Історія одного вбивці»). Молодий вчений. 2018. № 7 (1). С. 140-143.

6. Миллер Л.В. Художественный концепт как смысловая и эстетическая категория. Мир русского слова. 2000. № 4. С. 39-45.

7. Приходько А.М. Концепти і концептосистеми в когнітивно-дискурсивній парадигмі лінгвістики. Запоріжжя : Прем’єр, 2008. 332 с.

8. Сердюк О.В. Особливості вживання художніх концептів КІШКА та СОБАКА (на матеріалі творів художньої літератури). Вісник Харківського національного університету імені В.Н. Каразіна. Серія: Філологія. 2015. Вип. 73. С. 140-142.

9. Сергеева Е.В. К вопросу о классификации концепта в художественном тексте. Вестник Томского государственного педагогического университета. Серия: гуманитарные науки (филология). 2006. Вып. 5. С. 98-103.

10. Старостина Ю.А. Концепты «запах» и «красота» в романе П. Зюскинда «Парфюмер. История одного убийцы». Изв. Волгогр. гос. пед. ун-та. Сер.: Филологические науки. 2009. № 7 (41). C. 164-169.

11. Süskind P. Das Parfum. Die Geschichte eines Mörders. Zürich: Diogenes Verlag AG, 1985. 306 S.

\section{REFERENCES}

1. Guba L.V. (2018) Khudozhnii kontsept yak reprezentant poetychnoi movnoi svidomosti 
[Artistic concept as representative of poetic linguistic consciousness]. Molodyi vchenyi, vol. 3 (2), pp. 616-619.

2. Dotsenko R.I. (1971) Na pidstupakh do styliu pysmennyka [On the approaches to the style of the writer]. Vsesvit, vol. 9, pp. 114-117.

3. Kahanovska O.M. (2002) Tekstovi kontsepty khudozhnoi prozy (na materiali frantsuzkoi romanistyky seredyny XX storichchia) [Text concepts of prose (on the material of French novelistics of the middle of the twentieth century)]. Kyiv: vyd. tsentr KNLU, p. 292.

4. Kyryliuk S.V. (2016) Linhvokohnityvni kharakterystyky kontseptu WEG/ DOROHA v nimetskii narodnii kaztsi [Lingvocognitive characteristics of the WEG/ ROAD concept in the German folk tale]: avtoref. dys. kand. filol. nauk: 10.02.04. Zaporizhzhia, $20 \mathrm{p}$.

5. Liepukhova N.I. (2018) Osoblyvosti vidtvorennia kontseptosfery khudozhnoho tvoru pry perekladi ukrainskoiu movoiu (na materiali romanu P. Ziuskinda "Zapakhy. Istoriia odnoho vbyvtsi") [Peculiarities of reproduction of the conceptosphere of a work of fiction when translating into Ukrainian (on the material of P. Suskind's novel "Smells. The story of one killer")]. Molodyi vchenyi, vol. 7 (1), pp. 140-143.

6. Miller L.V. (2000) Hudozhestvennyiy kontsept kak smyislovaya i esteticheskaya kategoriya
[Artistic concept as a semantic and aesthetic category]. Mir russkogo slova, vol. 4, pp. 39-45.

7. Prykhodko A.M. (2008) Kontsepty i kontseptosystemy v kohnityvno-dyskursyvnii paradyhmi linhvistyky [Concepts and concept systems in the cognitive-discourse paradigm of linguistics]. Zaporizhzhia: Premier, $332 \mathrm{p}$.

8. Serdiuk O.V. (2015) Osoblyvosti vzhyvannia khudozhnikh kontseptiv KIShKA ta SOBAKA (na materiali tvoriv khudozhnoi literatury) [Features of the use of artistic concepts CAT and DOG (on the material of works of fiction)]. Visnyk Kharkivskoho natsionalnoho universytetu imeni V.N. Karazina. Seriia: Filolohiia, vol. 73, pp. 140-142.

9. Sergeeva E.V. (2006) K voprosu o klassifikatsii kontsepta $\mathrm{v}$ hudozhestvennom tekste [To the question of the classification of the concept in the artistic text]. Vestnik Tomskogo gosudarstvennogo pedagogicheskogo universiteta. Seriya: gumanitarnyie nauki (filologiya), vol. 5, pp. 98-103.

10. Starostina Yu. A. (2009) Kontseptyi ,zapah” i „krasota" v romane P. Zyuskinda „Parfyumer. Istoriya odnogo ubiytsyi" [Concepts "smell" and "beauty" in the novel "Perfumer. The story of one murderer" by P. Suskind]. Izv. Volgogr. gos. ped. un-ta. Ser.: Filologicheskie nauki, vol. 7 (41), pp. 164-169.

11. Süskind P. Das Parfum. Die Geschichte eines Mörders. Zürich: Diogenes Verlag AG, 1985. 306 S. 